\title{
Friedreich Ataxia and nephrotic syndrome: a series of two patients
}

\author{
Julianna E. Shinnick', Charles J. Isaacs ${ }^{1}$, Sharon Vivaldi ${ }^{2}$, Kimberly Schadt ${ }^{1}$ and David R. Lynch ${ }^{1,3^{*}}$
}

\begin{abstract}
Background: Friedreich Ataxia (FRDA) is a neurodegenerative disorder characterized by gait and balance abnormalities, sensory loss, weakness, loss of reflexes, and ataxia. Previously, two cases of FRDA and Nephrotic Syndrome (NS) have been reported. Here we report two additional individuals with NS and FRDA, providing further evidence for a possible connection between the two diseases and focusing on the neuromuscular responsiveness of one individual to corticosteroid treatment, an effect not previously described in FRDA.

Case presentations: We describe two patients with FRDA also presenting with NS. The first patient was diagnosed with FRDA at age 5 and NS at age 7 following the development of periorbital edema, abdominal swelling, problems with urination, and weight gain. The second patient was diagnosed with NS at age 2 after presenting with periorbital edema, lethargy, and abdominal swelling. He was diagnosed with FRDA at age 10. Nephrotic syndrome was confirmed by laboratory testing in both cases and both individuals were treated with corticosteroids.

Conclusions: Nephrotic syndrome may occur in individuals with FRDA, but was not associated with myoclonic epilepsy in our patients as previously described. It is unlikely that this association is coincidental given the rarity of both conditions and the association of NS with mitochondrial disease in model systems, though coincidental coexistence is possible. One patient showed neurological improvement following steroid treatment. Although neurological improvement could be attributed to the treatment of NS, we also identified some degree of steroid responsiveness in a series of patients with FRDA but without NS.
\end{abstract}

Keywords: Friedreich Ataxia, Nephrotic Syndrome, Steroid

\section{Background}

Friedreich Ataxia (FRDA) is a neurological disease resulting in gait and balance abnormalities, sensory loss, weakness, loss of reflexes, and ataxia. A recessive disorder, FRDA can also result in scoliosis, urinary dysfunction, diabetes mellitus, optic atrophy, hearing loss, sleep apnea, and hypertrophic cardiomyopathy [1-8]. The disease is caused by expanded guanine-adenine-adenine (GAA) repeats on both alleles of the FXN gene $(F X N)$ in $98 \%$ of patients. The remaining $2 \%$ of individuals with FRDA have an expanded triplet repeat on one allele and a point mutation or deletion on the other. FRDA is a mitochondrial disease, as the deficient protein in FRDA

\footnotetext{
* Correspondence: lynchd@mail.med.upenn.edu

${ }^{1}$ Departments of Pediatrics and Neurology, Children's Hospital of

Philadelphia, 502 Abramson Research Center, 3615 Civic Center Blvd,

Philadelphia, PA 19104-4318, USA

${ }^{3}$ Perelman School of Medicine, University of Pennsylvania, Philadelphia, PA 19104, USA

Full list of author information is available at the end of the article
}

(frataxin) is crucial for mitochondrial iron-sulfur cluster containing enzymes involved in oxidative phosphorylation and the Krebs cycle [9-12]. There is currently no therapy for FRDA, though several clinical trials are ongoing [13, 14].

Although few manifestations outside of the typical features have been identified in FRDA, one previous report suggests an association of nephrotic syndrome (NS) with FRDA [15]. In addition, related ataxias with coenzyme Q deficiency are associated with NS as are other mitochondrial disorders [16, 17]. Here we report 2 more individuals with NS and FRDA, providing further evidence for a possible connection between the two diseases and focusing on the responsiveness of one individual to corticosteroid treatment, an effect not previously described in FRDA.

\section{Case Presentations}

Patient 1: The patient is a 13 year old female of European descent (GAA repeat lengths $=650,1000)$. She 
presented with gait and balance difficulties at age 4 and was diagnosed with FRDA at age 5. At age 7, she developed periorbital edema, abdominal swelling, problems with urination, and a weight gain of $10 \mathrm{lbs}$ over 9 months. She was diagnosed with idiopathic NS after laboratory testing revealing a urine protein of $2854 \mathrm{mg} / \mathrm{dl}$ and albumin of $2.2 \mathrm{~g} / \mathrm{dL}$. Though renal biopsy was not performed, specific causes of secondary nephrotic syndrome were ruled out by clinical criteria and serological testing. She received prednisone pulse therapy at $30 \mathrm{mg}$ daily, which was tapered after 4 weeks. Her NS responded rapidly and urine protein levels normalized. She had 5 relapses of NS over the next 5 years, characterized by urine protein levels $>100 \mathrm{mg} / \mathrm{dL}$, all treated with 30-60 mg daily of prednisone pulse therapy. Clinical manifestations and laboratory parameters (proteinuria) of NS resolved following steroid treatment; surprisingly, neurologic improvements were also noted by her caregiver and physical therapist. Specifically, after her first treatment with prednisolone, the patient's physical therapist noted that she had maintained range of motion in her heel cords and hamstrings and retained her skill level in balance as related to single leg stance over the course of a year. In the year following a second steroid treatment, the patient demonstrated decreased balance, coordination and range of motion. Subjectively her sense of fatigue decreased and her endurance improved. Objectively, her gait improved with a narrower base and fewer falls.

The effect was most prominent in a worsening of her neurologic abilities following scoliosis surgery. Following surgery she again developed NS and became unable to walk. Corticosteroid treatment led to recovery of renal function as well as ambulation. However, as her steroids were tapered, she lost ambulatory ability. This improved with another pulse of steroid treatment in the absence of NS.

Patient 2: The patient is a 25 year old male of Indian descent with FRDA (GAA repeats lengths $=650,850$ ). At age 2, the patient presented with periorbital edema, lethargy, and abdominal swelling. Idiopathic NS was confirmed following urine protein testing. He developed gait difficulties at age 9 and was diagnosed with FRDA at age 10. He had been treated with chronic steroids from age 2 to age 10, with doses ranging from $15 \mathrm{mg}$ every other day to $60 \mathrm{mg}$ per day during episodic flares. In response to the onset of gait problems, the patient's nephrologist switched him from steroid treatment to $100 \mathrm{mg}$ of cyclophosphamide for 3 months. He has not had any relapses of NS since then. However, the patient's ataxia worsened after the discontinuation of steroids.

Given the improvement of the first subject on corticosteroid treatment, we examined the records of the Children's Hospital of Philadelphia (CHOP) and the
Collaborative Clinical Research Network (CCRN) for other individuals reporting responses to corticosteroids prescribed for other indications in a retrospective review (Table 1) [18]. Nine people with FRDA experienced improved balance, gait or speech with corticosteroid or other immunomodulatory therapy, and no individuals were identified with significant steroid dependent worsening. One other patient treated with steroids showed improvement, although it is unclear whether improvement was due to corticosteroids or other medications initiated at the same time. All patients besides patients 1 and 2 described had normal kidney function.

There are several limitations to this study. Improvement in the context of corticosteroid treatment often occurred in the context of significant clinical changes, such as NS in the case of the two cases presented and surgery or trauma in other FRDA patients treated with steroids. Furthermore, in two cases, steroid treatment was initiated following intravenous immunoglobulin G treatment prescribed for chronic inflammatory demyelinating polyneuropathy and Guillain-Barre syndrome, both likely misdiagnoses for Friedreich Ataxia. This raises the possibility that in these cases concomitant intravenous immunoglobulin $G$ treatment was at least partially responsible for noted improvements.

\section{Conclusions}

We describe two patients with FRDA and NS, one of whom demonstrated significant improvement with corticosteroid treatment. An association between FRDA and NS was initially reported in a single family in association with myoclonic epilepsy. Epilepsy was not identified in our subject, thus dissociating such findings (as predicted previously). As NS and FRDA are both rare, the present association in multiple unrelated subjects is unlikely to be coincidental. Furthermore, nephrotic syndrome has been documented in a variety of mitochondrial cytopathies and mutations in the synthesis of Coenzyme $\mathrm{Q}_{10}$ cause a subset of steroid-resistant nephrotic syndrome cases [19, 20]. Mitochondrial dysfunction is central to the pathophysiology of Friedreich Ataxia [21]. Lack of frataxin disrupts the production of ironsulfur clusters and increases levels of intracellular ROS in animal models,patient biopsies and FRDA fibroblasts, suggesting increased oxidative stress in FRDA cells $[10,22-24]$. Although the typical symptomatology of FRDA results from mitochondrial dysfunction in the spine, cerebellum and heart, we hypothesize that the cases of nephrotic syndrome in FRDA described result from mitochondrial involvement in renal cells.

Interestingly one of our subjects showed substantial neurological improvement following steroid treatment. No improvement in the non-neurological symptoms of FRDA were noted. Although this might represent a 
Table 1 Patients with FRDA treated with steroids

\begin{tabular}{|c|c|c|c|c|c|c|c|c|c|}
\hline $\begin{array}{l}\text { Patient No. GAA } \\
\text { repeats }\end{array}$ & $\begin{array}{l}\text { Age of FRDA } \\
\text { onset }\end{array}$ & Clinical course & Phenotype $^{a}$ & Immunomodulator & Dose & Duration & $\begin{array}{l}\text { Reason for steroid } \\
\text { treatment }\end{array}$ & Response & $\begin{array}{l}\text { Age of steroid } \\
\text { treatment }\end{array}$ \\
\hline $\begin{array}{l}\text { Patient } 1 \text { described } \\
650,1000\end{array}$ & 4 & $\begin{array}{l}\text { Began using } \\
\text { wheelchair at age 10; } \\
\text { scoliosis surgery at } \\
\text { age } 13\end{array}$ & $\begin{array}{l}\text { Ataxia, loss of balance, } \\
\text { loss of sensation, } \\
\text { leg cramps, tremors, } \\
\text { hypertrophic } \\
\text { cardiomyopathy, } \\
\text { scoliosis, fatigue }\end{array}$ & Prednisolone, oral & 30 BID-50 QD & $\begin{array}{l}26 \text { months } \\
\text { over } 6 \text { years }\end{array}$ & Nephrotic syndrome & $\begin{array}{l}\text { Recurrent neurologic } \\
\text { improvement } \\
\text { coincident with } \\
\text { steroid dosing }\end{array}$ & $8-14$ \\
\hline $\begin{array}{l}\text { Patient } 2 \text { described } \\
650,950\end{array}$ & 10 & $\begin{array}{l}\text { Began using } \\
\text { wheelchair at age } 12\end{array}$ & $\begin{array}{l}\text { Ataxia, loss of balance, } \\
\text { loss of sensation, } \\
\text { spasms, hypertrophic } \\
\text { cardiomyopathy, } \\
\text { arrhythmia, scoliosis }\end{array}$ & Prednisone, oral & unknown & 8 years & Nephrotic syndrome & $\begin{array}{l}\text { Possible delay in } \\
\text { presentation }\end{array}$ & $2-10$ \\
\hline $\begin{array}{l}\text { Patient } 3 \\
500,570\end{array}$ & 15 & $\begin{array}{l}\text { Began using cane } \\
\text { at } 23 \text {, wheelchair } \\
\text { at } 29\end{array}$ & $\begin{array}{l}\text { Ataxia, loss of balance, } \\
\text { loss of sensation, } \\
\text { leg spasms, restless legs, } \\
\text { scoliosis, sleep apnea }\end{array}$ & $\begin{array}{l}\text { Prednisone and } \\
\text { Medrol, oral }\end{array}$ & 8 QAM & 4-5 months & $\begin{array}{l}\text { Chronic inflammatory } \\
\text { demyelinating } \\
\text { polyneuropathy } \\
\text { (likely misdiagnosis) }\end{array}$ & $\begin{array}{l}\text { Mild improvements } \\
\text { in gait, eventual } \\
\text { progression }\end{array}$ & 18 \\
\hline $\begin{array}{l}\text { Patient } 4 \\
725, \text { presumed } \\
\text { point mutation }\end{array}$ & 7 & $\begin{array}{l}\text { Began using } \\
\text { wheelchair at } 17\end{array}$ & $\begin{array}{l}\text { Ataxia, loss of balance, } \\
\text { loss of sensation, } \\
\text { leg spasms, restless } \\
\text { legs, sleep apnea, } \\
\text { fatigue, hypertrophic } \\
\text { cardiomyopathy, } \\
\text { scoliosis }\end{array}$ & Prednisone, oral & 15-30 mg BID & 7 months & $\begin{array}{l}\text { Chronic inflammatory } \\
\text { demyelinating } \\
\text { polyneuropathy } \\
\text { (likely misdiagnosis) }\end{array}$ & $\begin{array}{l}\text { Improvements in } \\
\text { balance, eventual } \\
\text { progression }\end{array}$ & 12 \\
\hline $\begin{array}{l}\text { Patient } 5 \\
\text { unknown }\end{array}$ & unknown & Unknown & Unknown & Prednisone & unknown & unknown & Rib fractures & Improvement in Gait & unknown \\
\hline $\begin{array}{l}\text { Patient } 6 \\
1000,1000\end{array}$ & 3 & $\begin{array}{l}\text { Began using } \\
\text { wheelchair at age } 7\end{array}$ & $\begin{array}{l}\text { Ataxia, loss of balance, } \\
\text { loss of sensation, } \\
\text { leg spasms, restless } \\
\text { legs, increased tone, } \\
\text { tremor, hypertrophic } \\
\text { cardiomyopathy, } \\
\text { scoliosis }\end{array}$ & Prednisolone & unknown & unknown & $\begin{array}{l}\text { Chronic inflammatory } \\
\text { demyelinating } \\
\text { polyneuropathy } \\
\text { (likely misdiagnosis) }\end{array}$ & $\begin{array}{l}\text { Improvement in gait } \\
\text { and strength, } \\
\text { eventual progression }\end{array}$ & 3 \\
\hline $\begin{array}{l}\text { Patient } 7 \\
1113 \text {, point mutation }\end{array}$ & 2 & $\begin{array}{l}\text { Began using walker } \\
\text { at age } 5\end{array}$ & $\begin{array}{l}\text { Ataxia, loss of balance, } \\
\text { loss of sensation, } \\
\text { leg spasms, sleep } \\
\text { apnea, hypertrophic } \\
\text { cardiomyopathy, } \\
\text { scoliosis }\end{array}$ & $\begin{array}{l}\text { Methylprednisolone, } \\
\text { pulse therapy }\end{array}$ & $30 \mathrm{mg}$ QD & 5 days & Pneumonitis & $\begin{array}{l}\text { No change in gait, } \\
\text { balance, improved } \\
\text { energy }\end{array}$ & 6 \\
\hline $\begin{array}{l}\text { Patient } 8 \\
766,1000\end{array}$ & 7 & $\begin{array}{l}\text { Able to walk without } \\
\text { assistive device }\end{array}$ & $\begin{array}{l}\text { Minimal ataxia, loss of } \\
\text { balance, no scoliosis } \\
\text { or cardiac screening }\end{array}$ & Solumedrol, oral & $5 \mathrm{mg}$ TID & 5 months & Unclear & $\begin{array}{l}\text { Sustained } \\
\text { improvements in } \\
\text { balance, eventual } \\
\text { progression }\end{array}$ & 9 \\
\hline
\end{tabular}


Table 1 Patients with FRDA treated with steroids (Continued)

\begin{tabular}{|c|c|c|c|c|c|c|c|c|c|}
\hline $\begin{array}{l}\text { Patient } 9 \\
41,696\end{array}$ & 43 & $\begin{array}{l}\text { Began using a walker } \\
\text { at age } 58\end{array}$ & $\begin{array}{l}\text { Ataxia, loss of balance, } \\
\text { loss of sensation, } \\
\text { leg spasms, increased } \\
\text { tone }\end{array}$ & $\begin{array}{l}\text { Depomedrone, } \\
\text { injection }\end{array}$ & 80 mg QD & $7-9$ years & Sciatic pain & $\begin{array}{l}\text { Improvements in } \\
\text { gait and speech }\end{array}$ & 49 \\
\hline $\begin{array}{l}\text { Patient } 10 \\
966,1099\end{array}$ & 2 & $\begin{array}{l}\text { Able to walk without } \\
\text { assistive device }\end{array}$ & $\begin{array}{l}\text { Ataxia, loss of balance, } \\
\text { loss of sensation, fatigue }\end{array}$ & Prednisolone, oral & $30 \mathrm{mg}$ OPD & 3 days & Acute laryngotra-cheitis & $\begin{array}{l}\text { Improvements in } \\
\text { falling and fatigue }\end{array}$ & 8 \\
\hline
\end{tabular}

Phenotype at closest exam to steroid use 
secondary event associated with improvement in her NS, we identified some degree of steroid responsiveness in her independent of NS and in other patients with FRDA. This could represent an anti-inflammatory effect (as two other patients responded transiently to intravenous immunoglobulin G) or could be the result of other effects of corticosteroids such as increased strength as a compensatory mechanism for balance dysfunction. The former possibility seems most likely, as a secondary inflammatory response in FRDA has been revealed in autopsy studies and in alterations of immune pathways in microarray analysis $[11,12]$. This is felt to be the mechanism behind the well-documented response of Duchenne muscular dystrophy to corticosteroids $[25,26]$.

On the molecular level, it is possible that steroids modify the oxidative stress caused by frataxin deficiency and subsequent mitochondrial disease. This change in oxidative stress was hypothesized to be a cause for neurological improvement following steroid treatment in ataxia-telangiectasia [27]. The catabolic effect of steroids could provide a mechanism for the improvements seen in FRDA, as altered lipid metabolism has been documented in rat myocytes with diminished frataxin levels and in Drosophilia melanogaster [28, 29]. The present patient, taken with previous basic and scientific research, suggests the importance of pilot studies examining the efficacy of pulse steroid treatment as a potential therapy in FRDA.

\section{Consent}

Written informed consent was obtained from the patients for review of their records for publications. A copy of the written consent is available for review.

\section{Abbreviations}

FRDA: Friedreich's Ataxia; GAA: Guanine-Adenine-Adenine; NS: Nephrotic Syndrome; CHOP: Children's Hospital of Philadelphia; CCRN: Collaborative Clinical Research Network.

\section{Competing interests}

The authors declare that they have no competing interests.

\section{Authors' contributions}

JS compiled case series data and drafted manuscript; Cl compiled case series data; SV provided physical therapy notes and interpretation; KS contributed to case series data and provided critical direction for the paper; DL contributed to manuscript and provided critical direction for the paper. All authors read and approved the final manuscript.

\section{Authors' information}

DL is professor of Pediatrics and Neurology at the Perelman School of Medicine, University of Pennsylvania and founding physician in the Penn Medicine/CHOP Friedreich's Ataxia Center of Excellence. KS is the nurse practitioner for the Friedreich's Ataxia clinic at CHOP.

\section{Acknowledgments}

This work was supported by grants from the Friedreich Ataxia Research Alliance.

\section{Funding}

This study was sponsored by a grant from the Friedreich Ataxia Research Alliance. The funding body did not contribute to the design of the study; collection, analysis, and interpretation of data; or the writing of the manuscript.

\section{Author details}

'Departments of Pediatrics and Neurology, Children's Hospital of Philadelphia, 502 Abramson Research Center, 3615 Civic Center Blvd, Philadelphia, PA 19104-4318, USA. ²Department of Physical Therapy, Department of Rehabilitation, Children's Hospital of Philadelphia, King of Prussia Specialty Care and Surgery Center, 550 South Goddard Blvd, King of Prussia, PA 19406, USA. ${ }^{3}$ Perelman School of Medicine, University of Pennsylvania, Philadelphia, PA 19104, USA.

Received: 17 September 2015 Accepted: 5 January 2016

Published online: 12 January 2016

\section{References}

1. Delatycki MB, Corben LA. Clinical features of Fredreich Ataxia. J Child Neurol. 2012;27(9):1133-7.

2. Corben LA, Ho M, Copland J, Tai G, Delatycki MB. Increased prevalence of sleep-disordered breathing in Friedreich ataxia. Neurology. 2013;81(1):46-51.

3. Seyer LA, Galetta K, Wilson J, Sakai R, Perlman S, Mathews K, et al. Analysis of the visual system in Friedreich ataxia. J Neurol. 2013;260(9):2362-9.

4. Delatycki MB, Paris DB, Gardner RJ, Nicholson GA, Nassif N, Storey E, et al. Clinical and genetic study of Friedreich ataxia in an Australian population. Am J Med Genet. 1999;87(2):168-74.

5. Greeley NR, Regner S, Willi S, Lynch DR. Cross-sectional analysis of glucose metabolism in Friedreich ataxia. J Neurol Sci. 2014;342(1-2):29-35.

6. Rance G, Corben L, Barker E, Carew P, Chisari D, Rogers M, et al. Auditory perception in individuals with Friedreich's ataxia. Audiol Neurooto. 2010;15(4):229-40.

7. Lynch DR, Regner SR, Schadt KA, Friedman LS, Lin KY, St John Sutton MG. Management and therapy for cardiomyopathy in Fridreich's ataxia. Expert Rev Cardiovasc Ther. 2012;10(6):767-77.

8. Parkinson MH, Boesch S, Nachbauer W, Mariotti C, Giunti P. Features of Friedreich's ataxia: clinical and atypical phenotypes. J Neurochem. 2013;126(S1):103-17.

9. Puccio $\mathrm{H}$, Kœenig M. Recent advances in the molecular pathogenesis of Friedreich ataxia. Hum Mol Genet. 2000;9(6):887-92.

10. García-Giménez J, Gimeno A, Gonzalez-Cabo P, Dasí F, Bolinches-Amorós A, Mollá B. Differential expression of PGC-1alpha and metabolic sensors suggest age-dependent induction of mitochondrial biogenesis in Friedreich ataxia fibroblasts. PLoS One. 2011;6(6):e20666.

11. Michael S, Petrocine SV, Qian J, Lamarche JB, Knutson MD, Garrick MD, et al. Iron and iron-responsive proteins in the cardiomyopathy of Friedreich's ataxia. Cerebellum. 2006;5(4):257-67.

12. Koeppen AH, Ramirez RL, Becker AB, Bjork ST, Levi S, Santambrogio P, et al. The pathogenesis of cardiomyopathy in Friedreich ataxia. PLoS. 2006;10(3):e0116396.

13. Strawser CJ, Schadt KA, Lynch DR. Therapeutic approaches for the treatment of Friedreich's ataxia. Expert Rev Neurother. 2014;14(8):947-55.

14. Seyer L, Greeley N, Foerster D, Strawser C, Gelbard S, Dong Y, et al. Openlabel pilot study of interferon gamma-1b in Friedreich ataxia. Acta Neurol Scand. 2015;132(1):7-15.

15. Watters GV, Zlotkin SH, Kaplan BS, Humphreys P, Drummond KN. Friedreich's ataxia with nephrotic syndrome and convulsive disorder: clinical and neurophysiological studies with renal and nerve biopsies and an autopsy. Can J Neurol Sci. 1981;8(1):55-60.

16. Quinzii CM, Hirano M. Coenzyme $Q$ and mitochondrial disease. Dev Disabil Res Rev. 2010;16(2):183-8.

17. Martín-Hernández E, García-Silva MT, Vara J, Campos Y, Cabello A, Muley R, et al. Renal pathology in children with mitochondrial diseases. Pediatr Nephrol. 2005;20(9):183-8.

18. Regner SR, Wilcox NS, Friedman LS, Seyer LA, Schadt KA, Brigatti KW, et al. Friedreich ataxia clinical outcome measures: natural history evaluation in 410 participants. J Child Neurol. 2012;27(9):1152-8.

19. Emma F, Bertini E, Salviati L, Montini G. Renal involvement in mitochondrial cytopathies. Pediatr Nephrol. 2012;27(4):539-50. 
20. Ashraf S, Gee HY, Woerner S, Xie LX, Vega-Warner V, Lovric S, et al. ADCK4 mutations promote steroid-resistant nephrotic syndrome through CoQ10 biosynthesis disruption. J Clin Invest. 2013;123(12):5179.

21. González-Cabo P, Palau F. Mitochondrial pathophysiology in Friedreich's ataxia. J Neurochem. 2013;126(s1):53-64.

22. Babcock M, de Silva D, Oaks R, Davis-Kaplan S, Jiralerspong S, Montermini L, et al. Regulation of mitochondrial iron accumulation by Yfh1p, a putative homolog of frataxin. Science. 1997;276(5319):1709-12.

23. Puccio H, Simon S, Cossée M, Criqui-Filipe P, Tiziano F, Melki J. Mouse models for Friedreich ataxia exhibit cardiomyopathy, sensory nerve defect and Fe-S enzyme deficiency followed by intramitochondrial iron deposits. Nat Genet. 2001;27(2):181-6.

24. Rotig A, de Lonlay P, Chretien D, Foury F, Koenig M, Sidi D. Aconitase and mitochondrial iron-sulphur protein deficiency in Friedreich ataxia. Nat Genet. 1997:17(2):215-7.

25. Pane M, Fanelli L, Mazzone ES, Olivieri G, D'Amico A, Messina S, et al. Benefits of glucocorticoids in non-ambulant boys/men with Duchenne muscular dystrophy: A multicentric longitudinal study using the Performance of Upper Limb test. Neuromuscul Disord. 2015. doi:10.1016/..nmd.2015.07.009

26. Reeves EK, Rayavarapu S, Damsker JM, Nagaraju K. Glucocorticoid analogues: potential therapeutic alternatives for treating inflammatory muscle diseases. Endocr Metab Immune Disord Drug Targets. 2012;12(1):95-103.

27. Broccoletti T, Del Giudice E, Cirillo E, Vigliano I, Giardino G, Ginocchio VM, et al. Efficacy of very-low-dose betamethasone on neurological symptoms in ataxia-telangiectasia. Eur J Neurol. 2011;18(4):564-70.

28. Obis E, Irazusta V, Sanchis D, Ros J, Tamarit J. Frataxin deficiency in neonatal rat ventricular myocytes targets mitochondria and lipid metabolism. Free Radic Biol Med. 2014;73:21-33.

29. Navarro JA, Ohmann E, Sanchez D, Botella JA, Liebisch G, Moltó MD, et al. Altered lipid metabolism in a Drosophila model of Friedreich's ataxia. Hum Mol Genet. 2010;19(14):2828-40.

\section{Submit your next manuscript to BioMed Central and we will help you at every step:}

- We accept pre-submission inquiries

- Our selector tool helps you to find the most relevant journal

- We provide round the clock customer support

- Convenient online submission

- Thorough peer review

- Inclusion in PubMed and all major indexing services

- Maximum visibility for your research

Submit your manuscript at www.biomedcentral.com/submit

) Biomed Central 